\title{
Serum amyloid A protein concentration in progressive systemic sclerosis (scleroderma)
}

\author{
SYDNEY R. BRANDWEIN, THOMAS A. MEDSGER, JR, \\ MARTHA SKINNER, JEAN D. SIPE, GERALD P. RODNAN, * AND \\ ALAN S. COHEN
}

From the Thorndike Memorial Laboratory and Division of Medicine, Boston City Hospital, the Arthritis Center, Boston University School of Medicine (BUSM), Boston, MA; the Division of Rheumatology and Clinical Immunology, Department of Medicine, University of Pittsburgh School of Medicine, Pittsburgh, PA; and the Division of Rheumatology, Department of Medicine, Montreal General Hospital, McGill University, Montreal, Canada

SUMMARY Serum amyloid A protein (SAA) concentrations were determined in 62 patients with progressive systemic sclerosis (PSS). Forty-seven patients had normal or slightly elevated SAA levels $(<1000 \mathrm{ng} / \mathrm{ml}=\mu \mathrm{g} / \mathrm{l})$, while 15 patients had moderately to markedly elevated SAA levels, similar to those observed in active rheumatoid arthritis (RA) $(\geqslant 1000 \mathrm{ng} / \mathrm{ml}=\mu \mathrm{g} / \mathrm{l})$. Five patients with PSS had SAA levels corresponding to those observed in amyloidosis secondary to RA. High SAA was associated with more severe skin thickening and diminished cumulative survival at five years. The rarity of amyloidosis secondary to PSS is unlikely to be related to an intrinsic defect in SAA production.

Key word: amyloidosis.

Amyloidosis occurs as a complication of a number of rheumatic diseases including rheumatoid arthritis (RA), juvenile rheumatoid arthritis (JRA), and ankylosing spondylitis. ${ }^{1}$ Amyloid A protein (AA), which can be extracted from tissue amyloid deposits in chronic inflammatory disorders, is derived from the acute phase protein, serum amyloid A (SAA). ${ }^{2}$ Progressive systemic sclerosis (PSS, scleroderma) is a connective tissue disease characterised by fibrotic changes involving the skin, joints, heart, lungs, gastrointestinal tract, and kidneys. ${ }^{3}$ However, amyloidosis is rarely associated with PSS, having been reported previously in only six cases. ${ }^{4-7}$ The specific type of amyloid protein (primary AL or secondary AA) was not determined biochemically in these cases.

This study was undertaken to determine the SAA response associated with disease activity in patients with PSS, as the failure of SAA concentrations to rise would represent a possible explanation for the rarity of amyloidosis in this condition. SAA concen-

Accepted for publication 31 January 1984.

Correspondence to Dr S. Brandwein, Division of Rheumatology, Montreal General Hospital, 1650 Cedar Avenue, Montreal, Quebec, Canada H3G 1A4.

*Died on 24 November 1983. trations in association with disease activity have not previously been determined in patients with PSS, though individuals with PSS have been noted to have a defective acute phase SAA response after prostaglandin $\mathrm{E}_{1}\left(\mathrm{PGE}_{1}\right)$ infusion. ${ }^{8}$ However, the serum concentrations of other acute phase reactants, including C-reactive protein, alpha-1antitrypsin, and C3, have been shown to be elevated in one-third of patients with PSS. ${ }^{9}$

\section{Patients and methods}

Sera were obtained at the time of first evaluation from 62 patients with PSS examined at the University of Pittsburgh. The patients were divided in two groups, 31 having PSS and diffuse scleroderma and 31 having PSS and the CREST syndrome variant (calcinosis, Raynaud's phenomenon, oesophageal dysmotility, sclerodactyly, telangiectasia). Fifty-six of the 62 patients $(90 \%)$ fulfilled the preliminary ARA criteria for the classification of definite systemic sclerosis. There were 42 females and 20 males, with a mean age of 48.8 years. At the time the sera were obtained the mean disease duration was 6.5 years (range 0.2 to 30.5 years). Total skin score was determined as previously defined. ${ }^{10}$

Twenty-six patients fulfilling the ARA diagnostic 
criteria for classical or definite RA were examined at Boston University Medical Center. ${ }^{11}$ Seven of these patients had biopsy-proved amyloidosis. Thirteen of the 19 remaining patients with RA had markedly active disease, defined by a clinical activity score, while six patients had mildly active disease. ${ }^{12}$ Although the mean age of RA patients with or without amyloidosis was identical (60 years), the patients with amyloidosis had a longer duration of disease (mean $=29$ years, range 5-63 years) than those without amyloidosis (mean $=9$ years, range 1-30 years). Sera from 12 healthy volunteers were used for control SAA levels.

SAA was measured by solid phase radioimmunoassay as the ability of sera to compete with ${ }^{125}$ I-AA for binding to rabbit anti-human AA antibody immobilised on polyvinylchloride plates, as described previously. ${ }^{13}$ All sera were stored at $-20^{\circ} \mathrm{C}$ prior to determination of SAA. Normal values for this assay are less than $200 \mathrm{ng} / \mathrm{ml}(\mu \mathrm{g} / \mathrm{l})$. Slight elevation of SAA is defined as $200-999 \mathrm{ng} / \mathrm{ml}$ $(\mu \mathrm{g} / \mathrm{l})$, and moderate to marked elevation as 1000 $\mathrm{ng} / \mathrm{ml}(\mu \mathrm{g} / \mathrm{l})$ or more.

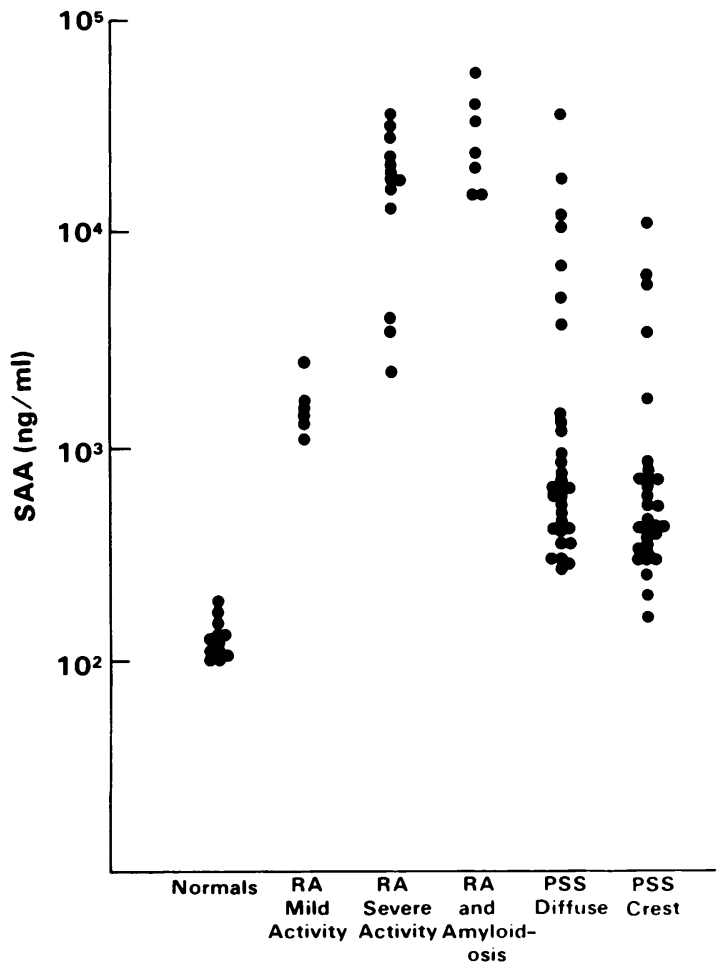

Fig. 1 SAA concentration ( $\mathrm{ng} / \mathrm{ml}=\mu \mathrm{g} / \mathrm{l}$ ) in PSS (diffuse or CREST syndrome) compared with $R A$, amyloidosis secondary to $R A$, and normal persons.

\section{Results}

SAA levels were determined in sera from 12 healthy volunteers and 26 patients with RA (Fig. 1). Normal SAA concentration was $129 \pm 8 \mathrm{ng} / \mathrm{ml}$ (mean \pm SEM). Six patients with mildly active RA had SAA concentrations of $1883 \pm 345 \mathrm{ng} / \mathrm{ml}$, while 13 patients with very active RA had SAA levels of $17954 \pm 2961 \mathrm{ng} / \mathrm{ml}$. In comparison, the SAA concentration in seven individuals with RA and secondary amyloidosis was $29443 \pm 5907 \mathrm{ng} / \mathrm{ml}$. (SI conversion: $\mathrm{ng} / \mathrm{ml}=\mu \mathrm{g} / \mathrm{l}$.)

Patients with PSS had a wide range of SAA concentrations (Fig. 1). Sixty-one $(98 \%)$ of the 62 patients had elevated SAA levels. Thirty-one patients with PSS and diffuse scleroderma had a median SAA concentration of $646 \mathrm{ng} / \mathrm{ml}$ (range 284-37 800), while 31 patients with PSS and CREST syndrome had a median SAA concentration of 448 $\mathrm{ng} / \mathrm{ml}$ (range 160-11 130). There was no significant difference in SAA concentration between the PSSdiffuse scleroderma and PSS-CREST syndrome groups by non-parametric statistical analysis.

For further analysis, 15 patients with moderately or markedly elevated SAA levels $(1000+\mathrm{ng} / \mathrm{ml})$ were compared with 47 patients with normal or slightly elevated SAA concentrations (less than 1000 $\mathrm{ng} / \mathrm{ml}$ ) (Table 1). Patients with high SAA levels tended to have more extensive and severe skin thickening (diffuse scleroderma). Ten high-SAAlevel patients had PSS-diffuse and five had PSSCREST. The patient with the highest SAA level (37 $800 \mathrm{ng} / \mathrm{ml}$ ) had diffuse scleroderma and renal insufficiency and subsequently died of this complication. The individual with the next highest level (18 $060 \mathrm{ng} / \mathrm{ml}$ ) had no evidence of visceral PSS at the time of study but died of cardiac complications six months later. The total skin score was higher in patients with high levels of SAA, and during follow-up this difference became statistically significant. There have been three deaths in the 15 patients with moderately or markedly elevated SAA compared with 4 in the 47 normal or mildly elevated SAA group. No infections or malignancies were identified in the high SAA patients. No associations were found between moderate to markedly elevated SAA and HLA-A, B, or D histocompatibility types, though admittedly the number of patients in each group is small.

\section{Discussion}

In the present study all but one PSS patient had at least a mildly elevated SAA concentration. Moreover, the SAA levels in a subgroup of $15(24 \%)$ PSS 
Table 1 Comparison of clinical and laboratory features in patients with moderately or markedly elevated SAA versus normal or mildly elevated SAA at first evaluation

\begin{tabular}{|c|c|c|c|}
\hline & $\begin{array}{l}\text { Moderate-marked } \\
\text { SAA elevation } \\
(n=15)\end{array}$ & $\begin{array}{l}\text { Normal-mild } \\
\text { SAA elevation } \\
(n=47)\end{array}$ & Significance \\
\hline \multicolumn{4}{|l|}{ Demographic information } \\
\hline Mean age (years) & $44 \cdot 2$ & $50 \cdot 3$ & \\
\hline Sex (\% women $)$ & 60 & 70 & \\
\hline Disease duration (years) & $7 \cdot 1$ & $6 \cdot 1$ & \\
\hline \multicolumn{4}{|l|}{ Clinical involvement ( $\%$ positive) } \\
\hline Raynaud's phenomenon & 87 & 91 & \\
\hline Skin (total skin score) & $30 \cdot 0$ & $17 \cdot 7$ & \\
\hline Joints (arthralgia, arthritis & 60 & 56 & \\
\hline or tendon friction rubs) & 13 & 2 & \\
\hline Gastrointestinal tract & 60 & 60 & \\
\hline Lungs & 27 & 32 & \\
\hline Heart & 13 & 4 & \\
\hline Kidneys & 7 & 0 & \\
\hline \multicolumn{4}{|l|}{ Laboratory abnormalities } \\
\hline Sedimentation rate $(\mathrm{mm} / \mathrm{h}$, Wintrobe $)$ & $28 \cdot 5$ & $22 \cdot 2$ & \\
\hline Serum complement $-\mathrm{C} 3(\mathrm{mg} / \mathrm{dl})$ & $140 \cdot 8$ & $126 \cdot 4$ & $\mathrm{p}<0.01$ \\
\hline FANA (positive in any titre) & $73 \%$ & $51 \%$ & \\
\hline \multicolumn{4}{|l|}{ Follow-up data } \\
\hline Highest total skin score & $43 \cdot 6$ & $21 \cdot 3$ & $\mathrm{p}<0 \cdot 01$ \\
\hline Cumulative survival at 5 years & $69 \%$ & $92 \%$ & \\
\hline
\end{tabular}

SI conversion: $\mathrm{mg} / \mathrm{dl} \times 10=\mathrm{mg} / \mathrm{l}$. FANA $=$ fluorescent antinuclear antibodies.

patients were in fact found to be in the same range as seen in patients with active RA. Several of the PSS patients displayed SAA concentrations similar to those observed in individuals with known amyloidosis secondary to RA. It was further noted that the subgroup of PSS patients with high levels of SAA had somewhat more severe disease at the time of initial examination, as determined by severity of skin thickening and other acute phase reactants (Table 1).

SAA production is mediated by a soluble macrophage-derived factor originally termed 'SAA inducer' and known to be closely related to interleukin 1 (IL 1). ${ }^{14}{ }^{15}$ Patients with PSS have been shown to have impaired acute phase SAA responses after infusion of $\mathrm{PGE}_{1} .{ }^{8}$ Preliminary studies indicated that leucocytes from patients with PSS have defective IL 1 production in response to stimulation with heat killed staphylococci. ${ }^{8}$ From these observations it was postulated that patients with PSS have impaired IL 1 production in the presence of active disease, and furthermore that a presumed resultant failure to significantly increased SAA levels explains the rarity of amyloidosis in PSS. However, in another preliminary study it was found that peripheral blood mononuclear cells from a small number of patients with PSS in fact elaborated increased amounts of IL 1 activity spontaneously compared with controls. ${ }^{16}$

Our study suggests that patients with PSS tend to have mildly elevated SAA levels, presumably as a result of low grade disease activity. With more active disease the acute phase SAA levels in PSS patients become comparable to those observed in active RA and amyloidosis secondary to RA. The rarity of amyloidosis associated with PSS does not seem to be related to an intrinsic defect in SAA production, but may be a result of the shorter duration of disease in patients with severe PSS, who have the highest SAA levels. This further suggests that elevated SAA levels are not necessarily indicative of amyloidosis and that other factors are important in the pathogenesis of amyloid deposition.

This research was supported by NIH grants AM 04599, AM 07014, AM 20613, AM 21393, RR 533, US Public Health Services grant FR-00056, and by grants from the Arthritis Foundation, the Kroc Foundation, the RGK Foundation, and the Arthritis Society of Canada.

\section{References}

1 Cohen A S. Amyloidosis. In: McCarty D J, ed. Arthritis and allied conditions. Philadelphia: Lea and Febiger, 1979: 905-17. 
2 Levin M, Franklin EC, Frangione B, Pras M. Immunologic studies of the major nonimmunoglobulin component of amyloid. I. Identification and partial characterization of a related serum component. J Exp Med 1973; 138: 373-80.

3 Rodnan G P. Progressive systemic sclerosis (scleroderma). In: McCarty D J, ed. Arthritis and allied conditions. Philadelphia: Lea and Febiger, 1979: 762-809.

4 Sackner M A. Scleroderma. New York: Grune and Stratton, 1966: 54-6.

5 Lowe W C. Scleroderma and amyloidosis. Milit Med 1969; 134: 1430-3.

6 Horwitz H M, DiBeneditto J D Jr, Allerga S R, Bauman H M. Scleroderma, amyloidosis and extensor tendon rupture. Arthritis Rheum 1982; 25: 1141-3.

7 Holzman H. Pericollagenous amyloid deposition in the skin and internal organs in scleroderma. Klin Wschr 1969; 47: 390-1.

8 Whicher J, Bell A, Unwin J, Martin M, Dieppe P. The prostaglandin-induced acute phase response is defective in endotoxin tolerant mice and in humans with scleroderma. In: Kushner I, Volanakis JE, Gewurz H, eds. C-reactive protein and the plasma protein response to tissue injury. Ann NY Acad Sci 1982; 389: 474-5.

9 Siebold J R, Iammarino R M, Rodnan G P. Alpha-I-antitrypsin in progressive systemic sclerosis. Arthritis Rheum 1980; 23: $367-70$.
10 Steen V D, Medsger T A Jr, Rodnan G P. D-penicillamine therapy in progressive systemic sclerosis (scleroderma). A retrospective analysis. Ann Intern Med 1982; 97: 652-9.

11 Ropes M W, Bennett G A. Cobb S, Jacox R, Jessar R A. 1958 revision of diagnostic criteria for rheumatoid arthritis. Bull Rheum Dis 1958; 9: 175-6.

12 Cooperating Clinics Committee of the American Rheumatism Association. A seven-day variability study of 499 patients with peripheral rheumatoid arthritis. Arthritis Rheum 1965: 8: 302-34.

13 Sipe JD, Ignaczak T F, Pollack P S. Glenner G G. Amyloid fibril protein AA: purification and properties of the antigenically related serum component as determined by solid phase radioimmunoassay. J Immunol 1976; 116: 1151-6.

14 Sipe J D, Vogel S N, Ryan J L, McAdam K P J W, Rosenstreich D L. Detection of a mediator derived from endotoxinstimulated macrophages that induces the acute phase serum amyloid A response in mice. $J$ Exp Med 1979; 150: 597-606.

15 Sztein M B, Vogel S N, Sipe J D, et al. The role of macrophages in the acute phase response: SAA inducer is closely related to lymphocyte activating factor and endogenous pyrogen. Cell Immunol 1981; 63: 164-76.

16 Sandborg C I, Berman M A. Andrews B S. Friou G J. Interleukin 1 production by mononuclear cells from patients with scleroderma syndromes. Arthritis Rheum 1983; 26 (suppl): S28 (abstr) 